\title{
ISSUES AND CHALLENGES OF SHARIAH COMPLIANCE AUDITING IN ISLAMIC FINANCIAL INSTITUTION
}

\author{
Mariawati Omar \\ School of Business and Economics, Universiti Brunei Darussalam (UBD). \\ (Email: mariawati.omar@gmail.com)
}

Received date: $16-10-2019$

Revised date: $23-10-2019$

Accepted date: 28-10-2019

Published date: 15-12-2019

To cite this document: Omar, M. (2019). Issues and Challenges of Shariah Compliance Auditing in Islamic Financial Institution. Advanced International Journal of Banking, Accounting and Finance, 1 (1), 13-24.

DOI: $10.35631 /$ aijbaf.11002

Abstract: The study examines the stakeholders' perspectives who are involved directly and/or indirectly with Shariah compliance auditing of Islamic financial institutions on the issues of Shariah auditing standards, auditors ' qualifications, and independence. Auditing Islamic financial institutions cover a broader scope than the financial statement auditing. The auditors are not only conducting financial audits but also conduct tests on the Shariah compliance according to Shariah resolution and guidelines set by the centralized Shariah Board and/ or the industry Shariah Body. The Shariah audit review is unique due to the requirement in ensuring that all business activities and operations adhere to Shariah principles. The limited resourceful auditors that possess both Shariah and technical accounting/auditing qualifications and the issue of independence may affect the reputable image of Islamic financial institutions. This study is based on a literature review from past studies. Evidence from past studies mostly emphasizes the importance of auditors' qualifications and independence in determining the Islamic financial market's growth. The paper suggests practical actions to regulators in formulating regulated professional governance structure for Shariah auditors.

Keywords: Shariah Auditing; Islamic Financial Institutions; Corporate Governance

\section{Introduction}

The Shariah audit function within the Islamic financial institutions (IFIs) provides assurance on IFI's compliance with Shariah principles. 
This study will examine the stakeholders' perspective who are involved directly and or indirectly with Shariah compliance auditing of IFIs on the issues of Shariah auditing standards, auditors' qualifications, and independence. This study is based on review of past literatures and the available information from the relevant official websites such as the international standard setters [Accounting and Auditing Organization for Islamic Financial Institutions (AAOIFI), Islamic Financial Services Board (IFSB) as well central banks Bank Negara Malaysia (BNM), Bank Indonesia (BI), Otoritas Jasa Keuangan (OJK), Autoriti Monetari Brunei Darussalam (AMBD)].

The theme on issues and challenges of Shariah compliance audit is highlighted from several studies such as Grais \& Pellegrini (2006); Abdul Rahman (2008); Mulyany (2008); Kasim et al., (2009); Yaacob \& Donglah (2012); Arwani (2018); Haridan et al., (2018). The issues and challenges highlighted from these studies include independence, confidentiality, qualification, inconsistency of pronouncements/ Shariah resolutions, scope and timing of audit, Shariah audit evidence, audit programmes and procedures and an independent regulatory body.

The paper is divided into five sections, beginning with an introduction, followed by a brief exploration of Shariah compliance audit with particular reference to AAOIFI and IFSB standard in Section 2. Then, in the next Section, the Shariah compliance audit practices in Malaysia, Indonesia and Brunei is presented. Section 4 will highlight on the issues and challenges of Shariah compliance auditing in the IFIs based on the previous studies. Lastly, a conclusion is drawn up with reference to limitations and potential avenue for further research.

\section{Brief History and Definition of Shariah Compliance Audit}

The history of auditing and its definition from AAOIFI and IFSB are as follows:

Shariah auditing from Quranic verses and Hadiths

a. Audit - Presentation and Discussion during the Reckoning (Hisab)

"Thou, verily O man, art working toward thy Lord a work which thou wilt meet (in His presence). Then whoso is given his account in his right hand. He truly will receive an easy reckoning. And will return unto his folk in joy" (Surah al'Insyiqaq: Verses 6-9);

b. Raqib and 'Atid are the best auditors

"Lo! There are above you guardians, Generous and recording, Who know (all) that ye do" (Surah Al- 'Infitar: Verses 10-12)

c. Prophet Sulaiman AS: Leading audit exercise

"And he sought among the birds and said: How is it that I see not the hoopee, or is he among the absent? I verily will punish him with hard punishment or I verily will slay him, or he verily shall bring me a plain excuse" (Surah al-Naml: Verses 20-21)

Auditing from Islamic point of view: the starting of Shariah Auditing - "Hisbah"

The concept of 'Hisbah' has been originated from the Islamic concept of "Ordering good and preventing the evil". 'Hisbah' started with the inception of Islam.

Accounting and Auditing Organisation for Islamic Financial Institution (AAOIFI) 
In its simplest sense, Shariah audit is defined as an audit attestation for Shariah compliance. However, the term is not so easy to be explained by such a simple expression.

AAOIFI Governance Standard for IFIs no. 3 (GSIFI 3) defined Internal Shariah review as "An independent department or part of internal audit examining and evaluating extent of compliance with Shariah rule, fatwas, instructions issued by the IFI's Fatwa and Shariah Supervisory Board".

Islamic Financial Services Board (IFSB) Standard No: 10 - Shariah Governance Systems for Islamic Institutions offering Islamic Financial Services (IIFS)

IFSB Standard 10 definition is "an internal Shariah compliance review/audit for verifying that Shariah compliance has been satisfied, during which any incident of non-compliance will be recorded and reported, and as far as possible, addressed and rectified".

\section{Shariah Compliance Audit Practices In Malaysia, Indonesia and Brunei}

\section{Shariah Compliance Audit In Malaysia}

Malaysia's Islamic financial system comprises of Islamic banks, Takaful operators, Development Financial Institutions and Islamic capital markets. The Islamic banks, Takaful operators, development financial institutions are governed by Bank Negara Malaysia (BNM), the central bank of Malaysia. Meanwhile, the capital market is under the authority of Securities Commission (SC) Malaysia. Malaysia has a two-tier Shariah Governance structure, one at a national level and another at the industry level.

\section{Role of BNM}

Malaysia being the leader in Islamic finance has no doubt has an advanced Islamic financial infrastructure. Shariah Governance Framework (BNM SGF) issued in the year 2010 has seen an encouraging initiative in the development of the Shariah compliant environment. The IFIs under BNM's jurisdiction are required to adhere to the requirements set out in the BNM SGF. Apart from the BNM SGF, the central bank has come up with another inspiring development in legislation when Islamic Financial Services Act (IFSA), 2013 was introduced. Part IV of the Act clearly mentioned on the Shariah requirements which is further divided into 3 divisions. The first division is on the Shariah compliance, followed by Shariah governance and Audit on Shariah compliance in the second and third divisions respectively. Specifically, on the third division on audit of Shariah compliance, section 37 of the Act required the IFIs to appoint person by institution to conduct audit on Shariah compliance. In addition to the Act, BNM also published a total of 14 Shariah standards and operational requirements which is really useful to the practitioners, academicians and other relevant stakeholders. The Shariah standards and operational requirements serve as one of the main references for the auditors in conducting the Shariah auditing.

The following provides the definition of Shariah audit, the scope of Shariah audit and the qualification of Shariah auditors as outline in the BNM SGF. 
a. Definition of the Shariah Audit

Shariah audit refers to "the periodical assessment conducted from time to time to provide an independent assessment and objective assurance designed to add value and improve the degree of compliance in relation to the IFI's business operations, with the main objective of ensuring a sound and effective internal control system for Shariah compliance" (BNM, 2010, p. 10).

The latest policy document from the BNM on the Shariah Governance (2019) also re-defines the Shariah audit as "a function that provides an independent assessment on the quality and effectiveness of the IFIs internal control, risk management systems, governance processes as well as the overall compliance of the IFIs operations, business, affairs and activities with Shariah" (BNM, 2017, p. 18).

b. Scope of Shariah Audit

The scope of the audit are as follows (BNM, 2010, p. 24):

i. audit of financial statements;

ii. compliance audit on organizational structure, people, process and information technology application systems; and

iii. review of adequacy of the Shariah governance process

The BNM also requires that in the event that the audit on financial statement is done by the external auditor, then IFIs has to satisfy that the scope is comprehensive.

c. Qualification of Shariah Auditors

According to the latest BNM's Shariah Governance, the Shariah auditor must be able to perform the following Shariah audit functions (BNM, 2010, p. 18):

i. establish an audit methodology to assess the risk profile and vulnerabilities of each auditable area;

ii. generate an audit plan for the assignments to be performed;

iii. establish clear documented audit programs that provide guidance to the internal audit assessment; and

iv. communicate results to the board and Shariah Committee (SC) through an audit report, dealing with the audit findings and recommendations for rectification measures, as well as the auditee's responses and action plans.

The Shariah auditors in IFIs must not only acquire the auditing skills but also need to have Shariah knowledge specifically in fiqh muamalat (Islamic business law). This is to make sure that proper Shariah audit has been performed and that the overall operations of IFIs are Shariah compliance.

The BNM adopt a flexibility approach in overcoming the knowledge gap of the auditors in terms of Shariah knowledge whereby the internal audit may engage the expertise of IFIs Shariah officers in conducting the Shariah audit provided that the objectivity of the audit is not compromised. 


\section{Shariah Compliance Audit In Indonesia}

Indonesia's Islamic financial market comprises of Shariah banks (Islamic banks), Islamic capital market, non-bank (such as Takaful operators) and these are governed under Otoritas Jasa Keuangan (OJK) or the Financial Services Authority. The OJK was established in 2011 to replace the role of Bapepam-LK in regulating and supervising the capital market and financial institutions, as well as that of Bank Indonesia in regulating and supervising the banks. Indonesia adopt a centralized Shariah governance structure, one at a national level and another at the industry level.

Based on the study conducted by Wardhany \& Arshad (2012), the following is the legislations that are applicable to the Islamic financial players:

Table 1: List of Applicable Legislation in Indonesia

\begin{tabular}{|l|l|}
\hline \multicolumn{1}{|c|}{ Title } & \multicolumn{1}{c|}{ Description } \\
\hline The Law No. 10 of 1998 & Conventional banks are allowed to have Shariah unit \\
\hline The Law No. 21 of 2008 & Shariah banking \\
\hline $\begin{array}{l}\text { Bank Indonesia Regulation } \\
\text { (PBI) No. 11/33/PBI/2009 }\end{array}$ & $\begin{array}{l}\text { Good Corporate Governance (GCG) implementation for } \\
\text { Shariah Commercial Banks and Shariah Business Units }\end{array}$ \\
\hline $\begin{array}{l}\text { Bank Indonesia Regulation } \\
\text { No. 11/3/2009 }\end{array}$ & About Full Fledged Shariah Bank \\
\hline
\end{tabular}

The following provides the literature on definition of Shariah audit, the scope of Shariah audit and the qualification of Shariah auditors.

a. Definition of the Shariah Audit

According to Wardhany \& Arshad (2012), there is no regulation yet pertaining to the Shariah audit, however, there is a requirement for the Shariah Supervisory Board to review the banks activity for Shariah compliance. Moreover, to comply with such requirement, the Shariah Supervisory Board is supported by an internal audit (ibid). According to the Bank Indonesia's regulation No. 11/33/PBI/2009 as cited in Wardhany \& Arshad (2012), the internal audit is obliged to report to the Shariah Supervisory Board with regard to Shariah compliance in the bank's activity.

b. Scope of Shariah Audit

As there is no regulation yet and with a limited literature, the scope of Shariah audit in the Indonesian context is yet to discover.

c. Qualification of Shariah Auditors

Based on a study done by Wardhany \& Arshad (2012), according to the Good Corporate Governance (GCG) Report, the bank has a Shariah compliance department under the compliance and risk management division with the responsibility to conduct Shariah review.

The qualification of the Shariah compliance department is they need to have Shariah based education background. 


\section{Shariah Compliance Audit in Brunei}

Brunei Darussalam's Islamic financial system consists of Islamic bank, Islamic trust fund, Takaful operators, Islamic capital market (securities, mutual funds), Islamic finance company and Islamic pawn broker. The licensed IFIs are governed under the Autoriti Monetari Brunei Darussalam (AMBD). Brunei Darussalam practices a two-tier Shariah Governance Framework, a national Shariah Financial Supervisory Board (SFSB) and Shariah Advisory Body (SAB) at the industry level. The SFSB was established in 2006 under the SFSB Order, 2006 with the objective to provide for the control of the administration and business dealings of financial institutions concerning Islamic products and any matters connected.

The following is the legislations that are applicable:

Table 2: List of Applicable Legislation in Brunei

\begin{tabular}{|l|l|}
\hline \multicolumn{1}{|c|}{ Market segment } & \multicolumn{1}{c|}{ Legislation } \\
\hline Islamic bank & Islamic Banking Order, 2008 \\
\hline Islamic trust fund & Perbadanan Tabung Amanah Islam Brunei Act, cap 163 \\
\hline Takaful & Takaful Order, 2008 \\
\hline Capital Market & Securities Market Order, 2013 \\
\hline Finance Company & $\begin{array}{l}\text { Finance Companies Act, cap 89 } \\
\text { Hire purchase Order, 2006 }\end{array}$ \\
\hline Islamic pawnbroker & Pawnbrokers Order, 2002 \\
\hline
\end{tabular}

Apart from the above, it is encouraging to note that the AMBD has recently issued a notice (IFAU/N1/2018) and guidelines (IFAU/G/2/2018) on the SGF to the IFIs in April 2018 with a grace period of 12 months to implement. This is a new development made by the authority in an effort to create a robust Shariah compliant environment.

The following provides the literature on definition of Shariah audit, the scope of Shariah audit and the qualification of Shariah auditors.

a. Definition of the Shariah Audit

Shariah audit is defined as "an independent and periodical assessment, conducted from time to time to provide objective assurance designed to add value and improve the degree of compliance of the Financial Institution's activities and operations. The main objective is to ensure a sound and effective internal control system for Shariah compliance" (AMBD, 2018, p. 26).

b. Scope of Shariah Audit

The scope of audit is as follows (AMBD, 2018, p. 26):

i. audit of financial statements;

ii. compliance audit on organizational structure, people, process and information technology application system, and pre-and post-approval process of products and services; and

iii. review of adequacy of the Shariah governance process. 
c. Qualification of Shariah Auditors

In terms of the qualification, the Shariah auditing is only to be performed by qualified internal audit with adequate knowledge on Shariah, Islamic finance and other relevant background (AMBD, 2018, p. 27). The IFIs may appoint external auditor with adequate knowledge on Shariah, Islamic finance and other relevant background to conduct the audit (ibid).

\section{Review of Literatures on Issues and Challenges of Shariah Compliance Audit}

Based on literatures, the theme on issues and challenges of Shariah compliance audit is highlighted from several studies such as Grais \& Pellegrini (2006); Abdul Rahman (2008); Mulyany (2008); Kasim et al., (2009); Yaacob \& Donglah (2012); Arwani (2018); Haridan et al., (2018). The issues and challenges highlighted from these studies include independence, confidentiality, qualification, inconsistency of pronouncements/ Shariah resolutions, scope and timing of audit, Shariah audit evidence, audit programmes and procedures and an independent regulatory body.

Abdul Rahman (2008) highlighted that Shariah compliance is principally internal. In other words, the Shariah compliance audit has to be conducted by the internal auditor. Although, this provide the stakeholders some level of confidence and trust in the IFIs, however, Chapra \& Ahmed (2012) highlighted there are issues and challenges such as independence, confidentiality, limited professional with both Shariah and financial skills. As a consequence, the Shariah Board rarely perform the ex-ante and ex-post on the operations of the IFIs (Abdul Rahman, 2008). To overcome the issues and challenges, Grais \& Pellegrini (2006) recommended the development of a framework both internal and external which emphasises on market discipline, that serve as a guidance to Shariah Board through standardisation and harmonisation. From the suggested framework, transactions review would be conducted by IFIs' internal review units, whereas, the external auditors are responsible for expressing an opinion on the Shariah compliance of the IFIs' operations.

Extending on the of the issues and challenges of Shariah audit, the perception of accounting and academicians, audit practitioners and Shariah scholars on the fundamental issues of Shariah auditing was empirically investigated by Mulyany (2008). The critical issues related to the understanding of the term "Shariah audit", the appointment of Shariah auditors and their qualification requirements, Shariah audit scope, the content of Shariah audit reports, regulatory framework for Shariah audit practice, and the Shariah auditing standards. Based on Mulyany, 2008, it was revealed that calls for proper Shariah audit definition, standardisation of certified Shariah auditors' qualification, identification of the scope, the extent and the timing of Shariah audit, the regulation and standardisation of the content of Shariah audit reports, the establishment of independent body to regulate and enforce the standards and the practical application of AAOIFI standards are required.

In an attempt to narrow down the gap between the theory and practice, the issues of Shariah audit framework, scope of work, qualification and independence of Shariah auditors have been empirically examined by Kasim (2009) which concluded that there exists a gap between the theory and the practice of Shariah Audit in IFIs. Similar with Grais \& Pellegrini (2006), a suggestion is made to further develop a Shariah audit framework, to widen the Shariah audit scope and to conduct regular independent Shariah audit. 
The research on issues and challenges, Shariah auditors are still perceived to be incompetent and lacking accountability and with compromised independence (Yaacob, 2012). Yaacob (2012) is of the opinion that Shariah auditors lack the accountability due to the absence of Shariah compliant inspectors. As a resolution to the independence threat and in ensuring accountability, he proposes the revitalisation of the institution of Hisbah based on its historical function in ensuring market players' compliance to the Shariah requirements.

The issue of Shariah auditing education has emerged, an extension to the issues and challenges. This research investigates the undergraduate students' awareness and understanding of the Shariah audit term and concept, as well as their recommendations for addressing Shariah audit issues and challenges (Yaacob \& Donglah, 2012). The issues include awareness and knowledge of Shariah audit, difference between conventional and Shariah audit, Shariah audit scope, timing, qualification, appointment of Shariah auditors, the right person to conduct Shariah audit, Shariah audit framework and independence of Shariah auditors. Based on Yaacob \& Donglah (2012), the students in Brunei have a low level of awareness and understanding of the term and concept of Shariah audit and they do not know the difference between the conventional and Shariah audit. The students are opined that Shariah audit should be performed throughout the financial year, the scope should cover every single activity on a sampling basis, Shariah auditors should have a degree or professional qualification in accounting and a specialised certification in Shariah audit, Shariah auditors should be appointed by the central bank, a new regulatory body should regulate the qualification and professional development of independent Shariah auditors. The study, however, only investigates the perceptions from the academic students and no emphasize on the professional training. The current market professional certifications on Shariah audit such as Certified Shariah Auditor (CSA) by AAOIFI, Certified Professional Shariah Auditor (CPSA) by Islamic Banking \& Finance Institute Malaysia (IBFIM) are value added to resolve on the issue of incompetency. Hence, future research can look at the perspective of other relevant stakeholders and to include on the need and awareness of such professional certifications. Also, the study by Yaacob \& Donglah (2012) was conducted before the issuance of Bruneian Guidelines on Shariah Governance Framework and Internal Shariah Audit Framework issued in 2018. The notable finding by the study on the low level of awareness and understanding on Shariah audit is of a great interest to find out on the impact of post implementation of mentioned Shariah regulations.

Moving from students to practitioners, the perspective of practitioners on the Shariah auditing issues and challenges has been conducted by Kasim and Sanusi (2013). The study examine the perception of practitioners engaged directly and/or indirectly in the process of Shariah compliance auditing from 21 IFIs in Malaysia on the issues of standards, the auditor's qualification and independence. The study has three important findings: (1) The practitioners are mainly following the conventional standards, although comparing it with AAOIFI's standards. (2) There is a shortage of auditors with both Shariah and accounting/ auditing qualifications. (3) Threat to their independence prevails due to the practice of self-review. These results further affirm the relevance of prior researchers' work on issues and challenges. They call on the Malaysia Institute of Accountants (MIA) or regulators to identify and implement integrated Shariah auditing practices, including developing a mandatory professional governance structure/ code and the full implementation of AAOIFI standards in Malaysia. Also, audit firms should create policies to ensuring that partners and teams auditing IFIs are qualified to undertake Shariah audit. They also 
propose for universities should include Shariah auditing courses or produce accounting graduates with minor in Shariah.

The comparative study by Kasim, Sanusi, Mutaminah \& Hanadoyo (2013) examine the extent of the current Shariah audit practice in Malaysian and Indonesian IFIs. The majority of the Indonesian respondents are external auditors from full-fledged IFIs with Shariah qualifications. While, the majority of the respondents from Malaysia comprise of the management of IFIs, with most of them having Shariah qualifications without much experience in auditing or accounting field. The study analyses four elements of Shariah compliance auditing practices: scope, regulatory framework, qualifications and the independence of Shariah auditors. The findings reveal that Indonesia is lacking in all of the four elements, whereas Malaysia has a limited scope of Shariah auditing.

Bahari \& Baharudin (2016) in their study mentioned that a comprehensive Shariah governance system would rely upon the management and supervision; the Shariah advisory board; Shariah compliance and review; the transparency and disclosure. Issues and challenges gathered include Shariah review report is voluntarily; depending on internal audit of IFIs; independence of Shariah auditors; insufficient number of Shariah expertise; Shariah committee report; the competency of Shariah committee. Notwithstanding these, the Shariah Governance Framework brings positive room of improvement to the IFIs.

Nomran et al. (2016) then highlighted on the performance of Shariah Board remained important in particular for Islamic banks across countries where the regulatory environment is different. The study examined on the effects of Shariah Board characteristics on the performance of Islamic banks in Malaysia covering 8 years' period from 2008 up to 2015. The variables used in this study are: board size; cross-membership; doctoral qualification; reputation; experience; total change in Shariah Board composition and remuneration. The study revealed that 5 variables are significantly relevant to the Islamic banks performance: size; doctoral; reputation; total change in composition and remuneration.

According to IFSB Standard No: 10 on Guiding Principles on Shariah Governance Systems (2009), Shariah Board is defined as a "specific body set up or engaged by the Institutions offering Islamic Financial Services (IIFS) to carry out and implement its Shariah Governance System". The IFSB also defined Members of the Shariah Board as "Shariah scholars, or ulama, who are equipped with not only general knowledge of Shariah or other disciplines, but more importantly have reached a specialised level in learning and expert in Fiqh Muamalat. That specialisation is then dedicated to providing expert opinions in the form of Shariah pronouncements/ resolutions, specifically to IIFS, beyond mere academic discourse and often not directly to the general public or to corporations in other industries".

Injas et al. (2016) has also studied on the impact of Shariah Board on the Islamic bank stability which concluded that SSB is vital in the Islamic bank like other departments. The SSB may exposed to some challenges such as the lack of decision making and the possible intervention by the management. Thus, with this restriction, it may eventually lead the Islamic bank into irregularities legitimacy and bring to adverse consequences. Further, this exposed the Islamic bank into Shariah non-compliance risk which is link with the reputation risk. 
Khalid (2017) in his study examine on the characteristics that influence the internal Shariah audit effectiveness in the kingdom of Bahrain, revealed that competency and the performance of work correlate positively with the effectiveness of Shariah audit. The competency includes professional certification and skills. Meanwhile, the work performance includes planning, engagement and adequate information in order to produce a sound view.

Based on a study by Arwani (2018), the present role of the Shariah Board emphasises on the compliance with rules, procedures and completeness of Shariah working paper. Thus, it can be deduced that IFI is easily can conform with the stipulated rules and procedures with no value added or achieving the objective of Shariah. In other word, the Shariah audit function is checking only to the extent of complying to rules and procedures.

On the other hand, a study conducted by Besar et. al. (2009) clearly indicate that IFIs need to promote external auditors' involvement in order to enhance the independence and transparency of the industry. Arwani (2018) further mentioned that the role of the external auditor with regard to Shariah compliance is only to test for compliance based on the outlines provided by the Shariah Board. Apart from the Shariah Board and external auditors, the other two key players involved in the audit of IFIs are the internal auditors and the Audit and Governance Committees especially on the socio-economic objectives (ibid).

There are several challenges identified by Arwani (2018) with regard to Shariah compliance auditing in IFIs. Firstly, in terms of the Shariah auditing standards. Despite the efforts undertaken by the AAOIFI, the scope of audit is focusing on dollars and cents in the financial statements instead of a broader concept of Shariah auditing involving the objective of Shariah. Secondly, in terms of the "true" owner who should be best to conduct the audit. Based on the AAOIFI standard, the Shariah audit function is distributed to external auditor, Shariah Board, Internal Shariah reviewer, Audit and Governance Committee. Third, is on the issue of Shariah Board independence as they are also responsible in issuing resolution/ endorsing the product to be launched to the market, and yet they also carry the Shariah review/ audit of the IFI concerned.

Another research conducted by Haridan et. al. (2018) highlighted concerns with regard to the general competency level of the individual Shariah Board member where they seem to be lacking technical banking and finance knowledge. The shortage of qualified Shariah Board members lacking appropriate knowledge could have a negative impact on the Shariah governance and hinder public trust and confidence. Thus, the competency of the Shariah Board members is fundamental to ensure an effective Shariah governance mechanism in the IFIs. The study highlighted that the composition of the Shariah Board members (Shariah and non-Shariah) could enhance the competency and capabilities in providing quality Shariah assurance.

The study by Haridan et. al. (2018) also provided a direct evidence that Shariah Board members who have less technical knowledge tend to delegate their role to the relevant internal officers of the IFIs. The internal officers will therefore perform the review and table the results to the Shariah Board for approval. Therefore, it appears that the Shariah Board decisions were made without proper due diligence as they were heavily reliant on the recommendations made by the internal officers. 


\section{Conclusion}

Shariah compliance is vital and the negative consequences will not only impact the financial but most importantly the effect is against the commands of Allah Subhanahu Wa Taala and impediment of Allah Subhanahu Wa Taala blessing.

In conclusion, there are still issues and challenges in Shariah compliance auditing from the aspect of Shariah auditing standards, Shariah auditor's qualifications and competency and their independence. Thus, it requires an urgent attention to close the gap as this may have an impact on the stakeholders' confidence on the Shariah compliance of the IFIs' products and services on its operations and activities.

This study is purely based on review of literatures and thus a fieldwork type research is recommended by doing a survey or questionnaires to the relevant stakeholders to find out the issues and challenges that they are facing in particular in the Brunei's Islamic finance industry.

With regard to policy implication, as highlighted in the previous literatures, one practical recommendation would be a collaborative effort between Association of Accountants and the central banks in charge of the IFIs, to come up with a comprehensive and integrated Shariah compliance framework in order to cater for the increase number of IFIs. This is fundamental as the Shariah auditors are likely to be different group of auditors with specialised qualifications both in Shariah and auditing/ accounting.

\section{References}

Abdul Rahman, A. R. (2008). Shariah audit for Islamic Finance services: the needs and challenges. International Shariah Research Academy for Islamic Finance (ISRA), Islamic Finance Seminar held in Kuala Lumpur.

Accounting and Auditing Organisation for Islamic Financial Institutions official website.

Autoriti Monetari Brunei Darusssalam official website.

Arwani, A (2018). Issues and Challenges of Shariah Auditing in Islamic Financial Institution and Corporate Governance Compliance", Media Riset Akuntansi, Auditing \& Informasi; Vol. 18, No. 2; ISSN 2442-9708

Bank Negara Malaysia official website.

Besar, M., Abd Sukor, M., Abdul Muthalib, N., \& Gunawa, A.Y. (2009). The practice of Shariah review as undertaken by Islamic banking sector in Malaysia. International Review of Business Research Papers, 5(1), 294-306.

Chapra, M.U., \& Ahmed, H. (2002). Corporate governance in Islamic financial institutions. Occasional Paper No. 6, Jeddah, IRTI/IDB.

Finance Companies Act, cap 89. Brunei Darussalam.

Gara, W., \& Pellegrini, M. (2006). Corporate governance in institutions offering Islamic financial services: issues and options (Vo. 4052). World Bank Publications.

Haridan, N. M, Hassan, A.F.S, Karbhari. Y. (2018). Governance, Religious Assurance and Islamic Banks: Do Shariah Boards effectively serve? https://doi.org/10.10007/s10997-018-9418-8

Hire Purchase Order, 2006. Brunei Darussalam

Islamic Banking Order, 2008. Brunei Darussalam

Islamic Financial Services Act, 2013. Malaysia http://www.bnm.gov.my/index.php?ch=en_legislation\&pg=en_legislation_act\&ac=222\& full=1\&lang=en 
Islamic Financial Services Board official website.

Islamic Financial Services Board: Standard No. 10 - Shariah Governance Systems for Islamic Institutions offering Islamic Financial Services.

Islamic Financial Services Board [IFSB] (2006). Guiding Principles on Corporate Governance for Institutions Offering Only Islamic Financial Services (Excluding Islamic Insurance (Takaful) Institutions and Islamic Mutual Funds). IFSB.

Kasim, N., Ibrahim, M., S., H., \& Sulaiman, M. (2009). Shariah auditing in Islamic financial institutions: exploring the gap between the "desirable" and the "actual". Global Economy \& Finance Journal, 2(2), 127-137.

Kasim, N., \& Sanusi, Z.M. (2013). Emerging issues for auditing in Islamic financial institutions. Empirical evidence from Malaysia. IOSR Journal of Business and Management, 8(5), 1017.

Kasim, N., Sanusi, Z.M., Mutamimah, T., \& Handoyo, S. (2013). Assessing the current practice of Aufiting in Islamic financial institutions in Malaysia and Indonesia. International Journal of Trade, Economics and Finance, 4(6), 414-418.

Mulyany, R. (2008). Shariah audit for Islamic financial institutions: perceptions of accounting academicians, audit practitioners, and Shariah scholars. Masters Dissertation, International Islamic University Malaysia.

Nurhastuty, Wardhany \& Shaista Arshad (2012). "The Role of Shariah Board in Islamic Banks: A Case Study of Malaysia, Indonesia and Brunei Darussalam", $2^{\text {nd }}$ ISRA Colloqium.

Otoritas Jasa Keuangan official website.

Pawnbrokers Order, 2002. Brunei Darussalam.

Perbadanan Tabung Amanah Islam Brunei, cap 63. Brunei Darussalam.

Shariah Financial Supervisory Board Order, 2006. Brunei Darussalam.

Shariah Governance Framework Autoriti Monetari Brunei Darussalam (2018)

http://www.ambd.gov.bn/SiteAssets/Pages/Legislation-And-

Regulations/Notice\%20to20\%Financial\%20Institution\%20on\%20Syariah\%20Governanc e\%20Framework.PDF

Shariah Governance Framework Bank Negara Malaysia (2010) http://www.bnm.gov.my/guidelines/05_shariah/02_Shariah_Governance_Framework_20 101026.pdf

Shariah Governance Exposure Draft Bank Negara Malaysia (2017) http://www.bnm.gov.my/index.php?ch=57\&144\&ac=648\&bb=file

Takaful Order, 2008. Brunei Darussalam.

Yaacob, H. (2012). Issues and challenges of Shariah audit in Islamic financial institutions: a contemporary view. $3^{\text {rd }}$ International Conference on Business and Economics Research, Bandung, Indonesia. 2669-2679.

Yaacob, H., \& Donglah, K., N. (2012). Shariah Audit in Islamic financial institutions: The postgraduates' perspective. International Journal of Economics \& Finance, 4(12).

Yaacob, H., Shafeek, F., \& Nahar, H., S. (2013). Exploring undergraduate students' understanding of Shariah Based Audit: Implications for the Future of Shariah Auditing Labor Market in Brunei. Asian Journal of Finance \& Accounting, 5(2), 84-100. 